\title{
Sosyal Pazarlamada Hazır Kitleyi Bulmak ve Haritalamak: Baby Boomers'larda Fiziksel Aktiviteye Yönelik Araştırma*
}

\author{
Dilşad ÇOKNAZ, Meftune ÖZBAKIR UMUT, Meltem NURTANIŞ VELIOĞLU**
}

Sosyal Pazarlamada Hazır Kitleyi Bulmak ve Haritalamak: Baby Boomers'larda Fiziksel Aktiviteye Yönelik Araştırma

Özet

Çalışmada Davranış Değişim Basamakları Modeli'ni kullanarak Baby Boomers kuşağından oluşan hedef kitleyi bölümlere ayırmak, bölümlerin fiziksel aktiviteye yönelik algıladığı fayda, engel ve motivasyon öğelerini belirleyerek hedef kitle haritası çıarmak amaçlanmıştır. Araştırma karma yöntem araştırması olarak desenlemiştir. Nicel verilerin analizinde betimsel istatistik, nitel verilerin analizinde içerik analizi yöntemleri kullanılmıştır. Hedef kitlede eğilim öncesi ve devamlılık bölümlerinde yoğunlaşma görülmüştür. Nitel bulgulara göre fiziksel aktivite ve dengeli ve düzenli beslenme sağlıkı yaşamın en önemli belirleyicileridir. Tüm pazar bölümlerinde fiziksel aktiviteden beklenen faydalarda fiziksel ve psikolojik sağlığa yönelik olanlar belirgindir. Algılanan engellerin başında zaman iklim, mekân, tek başına yapmanın sıkıcı olması gelmektedir. Motivlerden bazıları; kilo vermek, eğlenmek, ağrıları önlemek, iyi hissetmek (zindelik) ve hastalığını tedavi etmektir.

Anahtar Kelimeler: Sosyal Pazarlama, Hedef Kitle Haritası, Fiziksel Aktivite, Egzersiz Davranış Değişim Basamakları, Baby Boomers Kuşağı.
Identifying and Mapping Target Audience in Social Marketing: A Research on Physical Activity of Baby Boomers

Abstract

The aim of this study was to divide the target audience consisting of the "Baby Boomers" into segments and to determine their perceptions of benefits, barriers and motivations for physical activity to reveal a target audience map by using Stage of Change Model. The study was designed as a mix method. Descriptive statistics method in quantitative data analysis and content analysis method in qualitative data analysis were used. According to the results, "pre contemplation and maintenance segments were intense among the target audience. The qualitative data showed that physical activity and balanced and regular nutrition were the most important determinants of healthy living. In all market segments among the benefits expected from the physical activity, physical and psychological health benefits were the most significant. The most perceived barriers were: lack of time, climate, space, and being bored to do it alone. Some of the motives were: losing weight, having fun, preventing pain, wellness and therapy for an illness.

Key Words:Social Marketing, Target Audience Map, Physical Activity, Exercise Stage of Change, Baby Boomers

\footnotetext{
"Bu çalışma, 10-13 Haziran 2015 tarihinde Eskişehir'de yapılan 20. Ulusal Pazarlama Kongresi'nde özet bildiri olarak sunulmuş ve Prof. Dr. Mehmet Oluç üçüncülük ödülü almıştır.

** Dilşad ÇOKNAZ, Doç. Dr., Abant İzzet Baysal Üniversitesi, Spor Yöneticiliği Bölümü, coknaz_d@ibu.edu.tr; Meftune ÖZBAKIR UMUT, Yrd. Doç. Dr., Abant izzet Baysal Üniversitesi, işletme Bölümü, ozbakir m@ibu.edu.tr ; Meltem NURTANIŞ VELiOĞLU, Prof. Dr., Abant Izzet Baysal Üniversitesi, İşletme Bölümü, velioglu_m@ibu.edu.tr
} 
Dilşad ÇOKNAZ | Meftune ÖZBAKIR UMUT | Meltem NURTANIŞ VELIOĞLU

\section{Giriş}

Son 45 yıldır toplumsal fayda yaratan konu ve davranışları yaygınlaştırmada pazarlama alanında çalışanların ortaya koyduğu yeni ve yaratıcı sosyal pazarlama yaklaşımının, fiziksel aktiviteyi artırma, sağlıklı beslenme, organ bağışında bulunma, sigarayı bırakma, alkol ve uyuşturucu bağımlılığı, çevre kirliliğini önleme gibi davranışların geliştirilmesinde kullanıldığı görülmektedir (Dollatabady, Amiri ve Bidmeshk, 2012; Helmig ve Thaler, 2010). Özellikle fiziksel aktivite, beslenme ve sigarayı bırakma gibi konular ile ilgili çalışmalardan elde edilen kanıtlar ise sosyal pazarlamanın sağlık ilişkili davranışları değiştirebileceğini ortaya koymaktadır (Evans, 2007; Evans, 2008; Evans, Christoffel, Necheles, Becker ve Snider, 2011; Rayner, 2007).

Sosyal pazarlama, bir hedef kitlenin davranışlarını hem o hedef kitleye, hem de genel olarak topluma fayda sağlayacak şekilde etkilemek için pazarlama ilke ve yöntemlerini kullanan süreç olarak tanımlanır (Kotler ve Lee, 2008). Hedef kitle seçimi ve hedef kitleyi anlama ise sosyal pazarlama programının başarılı olabilmesinde önemli bir öğedir (Donovan, Paterson ve Francas, 1999, s.133). Bilindiği üzere pazarın bölümlenmesi, pazarın benzer potansiyel tüketicilerden oluşan farklı gruplara ayrılmasıdır (Kotler ve Armstrong, 2012, s.214). Sosyal pazarlamada da durum benzerdir. Kotler, Roberto ve Lee (2002) sosyal pazarlama programlarının hazırlanması ve uygulanmasında pazarı bölümleme, her bir bölümü değerlendirme ve bu gruplardan birine ya da birkaçına odaklanmayı önerir. Bu yüzden sosyal pazarlama programına başlamadan önce hedef pazarı bölümlere ayırarak her bir bölümü tanımlayıp, davranış ve tutumlarını belirlemek oldukça önemlidir. Çünkü sosyal pazarlamada hedef pazar seçimi; program süresince verilecek mesajı, mesajın hangi kanaldan verileceğini ve mesajın içeriğini belirleyen en önemli öğedir (Kolodinsky ve Reynoldsi, 2009,s.10).

Hedef pazar seçiminde pazarın hangi değişkenlere göre bölümlere ayrılması gerektiği pazarlama literatüründe sıklıkla tartışılan konulardandır. Birçok farklı değişken dikkate alınarak pazar bölümlere ayrılabilirken, literatürde coğrafik, demografik, psikografik ve davranışsal olmak üzere dört temel değişkenin kullanıldığı görülür (Kotler ve Armstrong, 2012). Örneğin Havai 'de yaşayan yetişkinlerin fiziksel olarak aktif olmalarının amaçlandığı sosyal pazarlama programında, hedef pazar; etnik kimliklere göre farklı bölümlere ayrılarak, sonuçta her bölüm için farklı mesaj stratejisi belirleme gerekliliği ortaya konulmuştur (Buchthal, Doff, Hsu, Silbanuz, Heinrich, ve Maddock, 2011). Bununla birlikte hedef pazar seçiminde kullanılacak değişkenlerin seçimi için kılavuzluk edecek en önemli öğe, değiştirilmek istenilen davranışın özellikleridir. Örneğin ilgili davranış değişikliğini yapması beklenen kişinin cinsiyeti, o davranışı sergileyebilmesi açısından önemli değilse, pazarı cinsiyet değişkenine göre bölümlere ayırmanın anlamı olmayacaktır. Ayrıca bir pazarın hedef pazar seçilebilmesi için gerekli olan dört öğe -ölçülebilir olması, erişilebilir olması, belli bir büyüklüğü olması, ayırt edilebilir olması- sosyal pazarlama için de geçerlidir (Jones, Rees, Hall ve Tang, 2005, s.145).

Sosyal pazarlamada hedef pazar seçimi için pazar bölümlendirmede bahsi geçen geleneksel değişkenlere ek olarak farklı modeller de kullanılmaktadır. Modellerin en sık kullanılanları "Davranış Değişim Basamakları Modeli (D.D.B.M.)”, "Yeniliklerin Yayılması Modeli”, "Sağlık İnancı Modeli", “Planlanmış Davranış Teorisi” ve "Sosyal Norm Modeli"dir (Kotler vd., 2002; Truong, 2014; Truong, Garry, ve Hall, 2014). Fiziksel aktivite, dengeli beslenme, bağımlılık gibi konularda ise D.D.B.M.'nin 
(Prochaska, DiClemente ve Norcross, 1992) daha sık kullanıldığı görülür. Bu model doğrultusunda pazar bölümlendirmede bireylerin davranış değişim aşamaları belirlenip, buna uygun programlar geliştirilirse başarı şansının artacağına yönelik öngörüler bulunmaktadır (Donovan vd., 1999; Kerr, Fridinger ve Volansky, 1999; Kotler vd., 2002).

D.D.B.M'nin sosyal pazarlamada tercih edilir olmasının bir başka nedeni, sosyal pazarlamanın davranış değişimine odaklı yapısında yer alan "değişime en hazır olan hedef kitle ile başlama” (Kotler vd., 2002) stratejisidir. Değişime en hazır kitleyi bulmaya yardımcı olacak bu model ilk kez Prochaska ve DiClemente tarafından 1980 yılında geliştirilmiş ve zaman içinde denenerek daha iyi hale getirilmiştir (Kotler vd., 2002). Modelde davranış değişiminin beş aşaması; eğilim öncesi, eğilim, hazırlık, hareket ve devamlılık olarak isimlendirilmiştir. Prochaska vd. (1992) tarafından tanımlanan bu beş aşama kısaca şu şekilde açıklanmıştır: Eğilim öncesindeki bireyin davranış değişimine yönelik bir niyeti yoktur ve gelecek altı ay içinde de davranışını değiştirmeyi düşünmemektedir. Bu aşamadaki pek çok birey aslında davranış değişimini gerektiren konu hakkında sorun algılamamaktadır. Eğilim aşamasında ise davranış değişimini gerekli kılan sorunun varlığına ilişkin farkındalık vardır ve birey gelecek altı ay içinde bu davranışı gerçekleştirmeyi düşünmektedir. Yani birey ne yapması gerektiğini bilmesine karşın henüz davranış değişimi için yeterince hazır değildir. Hazırlık aşamasında, niyete ve davranışa ilişkin öğeler bir aradadır. Birey çok yakın zamanda, örneğin gelecek ay içinde harekete geçmeye yönelik güçlü niyet taşımaktadır. Çünkü bireyin daha önce sorun oluşturan davranışı değiştirmeye yönelik girişimleri olmuştur. Bu aşama aynı zamanda karar verme olarak da adlandırılır. Modelin sonraki aşaması olan harekette, bireyler sorunlarını çözmek üzere davranış, deneyim ve çevrelerini değiştirmeyi planlamaktadır. Bu aşamadaki bireyler "davranışımı değiştirmek için gerçekten çok çalışıyorum" ya da " biri değişim hakkında konuştuğunda gerçekten onunla ilgili bir şeyler yapmak istiyorum" diyebilmektedir. Son aşama devamlılıktır. Bu aşamadaki bireyler söz konusu davranışı altı aydan az veya daha fazla süredir gerçekleştirmektedir.

Sosyal pazarlamada, D.D.B.M. ile bölümlerin belirlenmesinden sonraki süreç, davranış değişim aşaması ile tanımlanabilecek pazar bölümlerinin derinlemesine analizi ile devam etmelidir. Çünkü davranış değişiminin her bir aşamasında (her pazar bölümünde) yer alanların, değiştirilmek istenen davranışa ilişkin algıladıkları faydaları, engelleri ve motive eden öğeleri bilmek sosyal pazarlamacının hedef kitleye en etkili şekilde nasıl ulaşılacağına ilişkin yol gösterici olacaktır (Weinreich, 1999). Kısaca sosyal pazarlamanın, davranış değişimini gerçekleştirmede başarıya ulaşmasını sağlamak için tüketici davranışına odaklanma, pazar araştırması yapma, dikkatli biçimde pazarı bölümleme, pazar bölümleri açısından değiştirilmek istenen davranışın ayrıntılarını ve davranış karşısındaki gerçek rekabet koşullarını anlama çok önemlidir. Bahsi geçen bu aşamaların gerçekleştirilmediği sosyal pazarlama programlarının başarısızlıkla sonuçlanma olasılığı yüksektir (Andreasen, 1995; akt: Neiger, Thackeray, Barners, ve McKnezie, 2003; Smith, 2009). Bu nedenle çalışmanın konusunu oluşturan fiziksel aktivite davranışının yaygınlaştıııması için hazırlanacak sosyal pazarlama programları açısından da benzer şekilde düşünülmeli ve hareket edilmelidir. Halihazırda sosyal pazarlama, düzenli fiziksel aktivitenin yaygınlaştırılmasında etkili bir yöntem olarak kabul edilmekte ve bu yönlü çabaları destekleyecek güçlü potansiyele sahip olduğu bilinmektedir (Fujihira, Kubacki, Ronto, Pang ve Rundle-Thiele, 2015; Syme, 2002; Stead, Gordon, Angus ve McDermott, 2007). 
"Günlük yaşam içerisinde, iskelet kasları kullanılarak yapılan ve enerji harcamasını gerektiren hareket" (Türkiye Fiziksel Aktivite Rehberi, 2014) şeklinde tanımlanan fiziksel aktivite her yaştan insanın sağlı̆̆ının korunması ve iyileştirilmesi açısından oldukça önemlidir. Ancak bilinen tüm faydalarına karşın insanların fiziksel aktiviteye katılımı yeterli oranda değildir. Dünya Sağlık Örgütü’nün 2008 yılı verileri, her yıl yaklaşık 3.2 milyon ölümün fiziksel aktivite yetersizliğine bağlı sağık sorunlarından kaynakladığını ortaya koyarken, hareketsizliği küresel anlamda bir sağlık sorunu olarak kabul etmektedir (WHO, 2016)

Ülkemiz açısından bakıldığında fiziksel aktivite yetersizliği yaşla beraber artmakta, 31- 50 yaş grubu erkeklerde oran yüzde 73.2'ye, 75 yaş üzeri erkeklerde ise yüzde 83.7'ye kadar yükselmekte ve bu oranlar kadınlarda da benzerlik göstermektedir. "Kronik Hastalıklar Risk Faktörleri Araştırması"na göre ülke genelinde; kadınların yüzde 87'si, erkeklerin ise yüzde 77 'si yeterli ölçüde fiziksel aktivite yapmazken, 65 yaş üzeri bireylerin sadece yüzde 30'u yürüyüş yapmaktadır (Türkiye Fiziksel Aktivite Rehberi, 2014). Yapılan çalışmalar yıllar içerisinde (1990-2000) ve özellikle kadınlarda sedanter olma oranlarının da arttığını göstermektedir (Balcı, 2012).

1943-1960 yılları arasında doğanlar “Baby Boomers Kuşağı (B.B.K.)” olarak adlandırılmaktadır (Oh ve Reeves, 2014, s.820). B.B.K. tanımı her ne kadar ABD menşeili olsa da farklı ülkelerin istatistik büroları ve literatür çalışanları tam bir zaman aralığı birliğine varamamakla birlikte ülkeler, kendi yaşadığı politik, sosyolojik ve özellikle II.Dünya Savaşı sonrası nüfusu artırma eylem planları süreçlerine bağlı olarak B.B.K.'ya ilişkin doğum yılı aralığı belirleyerek kuşağı tanımlamışlardır; 1946-1964- (Amerika Birleşik Devletleri (ABD) İstatistik Kurumu, 2006; Hogan, Perez ve Bell, 2008; Sago, 2000; Crumpacker ve Crumpacker, 2007). Türkiye'de (TUiK, Başbakanlık vb. ) resmi organlarca belirlenmiş “B.B.K.'na atıfta bulunulan yıl aralığı” bulunmamakla birlikte "TUiK-Nüfus, yıllık nüfus artış hızı ve yıl ortası nüfus tahmini, 1927-2000 verisi" literatürün belirttiği savaş sonrası nüfus artışının "bebek patlaması" kavramını desteleyecek biçimde Türkiye için de yaklaşık olarak 1943-1960 aralığına uygun olduğu görülmektedir (Bakınız: Tüik Genel Nüfus Sayımları, 1927-2000, http://www.tuik.gov.tr/PreTablo.do?alt_id=1047, Erişim Tarihi 02.02.2016). Cumhuriyetin ilk yıllarında sağlık hizmetlerine verilen önemin artışı, özellikle anne ve çocuk sağlığı gibi konulara gösterilen ilgi, çok çocuk sahibi olmanın özendirilmesine yönelik uygulanan vergi muafiyetleri (1929-1931), ilaç yardımları (1930), düşük ve gebeliği önleyici ilaç ve araçların satılması, kullanılması ve bu konuda eğitim ve propaganda yapılmasının yasaklanması uygulamalarıyla (Güriz, 1971; Arı, 1992) desteklenmiş; yine de 1940'lara kadar nüfus artış hızı düşük kalmıştır (Bertan ve Özçebe, 1993; Kişniş̧̧i, 1991). Türkiye'de Cumhuriyetin ilk yıllarında devlet, nüfus artışını destekleyici, doğum kontrolünü yasaklayıc politikaları öncelerken 1960 'ı yıllardan başlayarak aile ve nüfus planlaması kavramı gündeme gelmiş, nüfus artışını destekleyici önlemlerden vazgeçme eğilimi güçlenmiştir (Özcan, 1993; Doğan, 1993; Terzibaşıŏlu, 1964). İlgili veriler ışığında araştırmanın B.B.K. aralığının Türkiye adına 19431960 aralığında değerlendirilmesi uygun görülmekte ve ülkemizde son 60 yılda iki kat artan yaşı nüfusun daha fazla büyüyeceğinin tahmini (TÜiK, 2013) gelecek dönemin B.B.K. olacağı sinyalini vermekte; bu kuşağın "tüketici davranışları ve sosyal pazarlama" kapsamında ele alınmasının önemi ortaya çıkmaktadır. 
Veriler bugün itibarıyla 56-73 yaş aralığında yer alan B.B.'ların Türkiye'de fiziksel aktivite açısından en yetersiz grubu oluşturduğunu göstermektedir. Oysa Stein ve Potkanowicz’e (2003) göre B.B.'lar bir önceki kuşağa göre daha uzun yaşılıık dönemi geçirecekleri öngörüsü ile sağlıklarına daha fazla dikkat etmesi gereken bir kuşaktır.

Sağlık Bakanlığı, Gençlik ve Spor Bakanlığı, Türkiye Halk Sağlığı Kurumu, Türk Geriatri Derneği, Halk Sağlığı Uzmanları Derneği gibi kurumlar Türkiye'nin sağlıklı yaşlanmasında fiziksel aktivitenin önemine dikkat çekerken, fiziksel aktivitenin özendirilmesine ve yaygınlaştırılmasına yönelik çalışmalara olan ihtiyacı da açıkça ortaya koymaktadır. Bu noktada B.B.K. sağılık hizmetleri açısından özel bir anlam kazanmaktadır. Salgın hastalıkların kontrol altına alınması, uzun yıllar süren savaşların azalması gibi etkenler ile eski çağlara oranla insanoğlu daha uzun yaşamaktadır. Günümüzde toplumların yaşam standartlarının yükselmesi, gelir düzeyinin artması, sağlık hizmetlerindeki gelişmeler sonucunda, uzun yaşama yani yaşlanma süreci uzamaktadır (Bilir, 2007). Günümüzde halen iş hayatında aktif olanları, emeklileri ve uzun zamandır emekli olan orta yaş üstü ve yaşıların oluşturduğu Baby Boomer Kuşağı (B.B.K.)'nın onlardan önceki kuşağa göre daha iyi koşullarda yaşadıkları ve daha sağlıklı bir yaşam tarzları olduğu için daha uzun yaşayacakları öngörülmektedir (Black, Wilson, O'Loughlin, Noone, Kending ve Butcher, 2013, s.1). B.B.K'nın bir önceki kuşağa göre farklı özellikleri ve farklı yaşlıık süreci yaşayacakları öngörüsünün nedenleri; önemli toplumsal değişimlere tanıklık etmiş olmaları, önceki kuşağa göre daha iyi eğitimli, daha deneyimli, daha sık seyahat etme şansına sahip olmaları, pazarlama mesajlarına ve çeşitli medya kanallarına daha fazla maruz kalmaları gibi özellikleridir (Quine ve Carter, 2006, s.4). Bu bireylerin takım çalışmasına ve işbirliğine önem veren, grupça karar vermeyi seven ve rekabetçi yapıya sahip olmaları fiziksel aktivitelere yatkın olabileceklerini göstermektedir (Tolbize, 2008, s.3). Ayrıca B.B'ların bir önceki kuşağa oranla daha sağılılı olmaları, eğitim seviyelerinin daha yüksek olması buna bağlı yaşam standartlarının yükselmesi ve teknolojik gelişmeleri takip edebilmeleri diğer özellikleri arasındadır (Maples ve Abney, 2006, s.3). Halen iş dünyasında olup, profesyonel çalışma yaşamlarını devam ettiren ancak emeklilik yaşlarına yaklaşan ve emeklilik planları yapmaya başlayacak olan B.B.'lara sağlıklı yaşlanmaları için uygulanması gereken programların; kilo yönetimi, beslenme düzeni, fiziksel aktivite programları, sağlık koçluğu, kronik hastalık yönetimi, tüketici sağlığı eğitimi gibi konulara odaklanması gerekir (Musich, McDonald ve Chapman, 2009, s.7). Özellikle Amerika Birleşik Devletlerinde (ABD) orta yaş üstü ve yaşlılar için geliştirilmiş "boş vakit geçirme merkezleri” B.B.K. dan önceki kuşağa hitap eden daha çok pasif ve fiziksel olarak fazla aktif olamadıkları programları içermektedir. Ancak yapılan çalışmalar son birkaç yılda orta yaş üstü ve yaşlılar grubuna giren B.B.'ler için bu merkezlerin programlarını revize etmeleri gerekliliğini, B.B.K.'nın bir önceki kuşağın aksine fiziksel olarak daha fazla aktif zaman geçirmek istediklerini göstermektedir. Bu merkezlerin diğer kuşağın ihtiyaç duymadığı bilgisayar donanımının ve Internet erişiminin olması, düşük-orta-yüksek seviyede fiziksel aktivitelerin yapılabileceği olanaklarının olması ayrıca konforlu ve rahat hareket edebilecekleri şekilde düzenlenmiş olması gerekmektedir (Bouck, 2013, ss.46-51). Avustralya'da B.B.K. ile ilgili yapılan araştırmada, B.B.K.'nın yaşlandıklarında mevcut yaşam tarzlarını devam ettirebilmek için onlardan önceki kuşağa göre daha fazla sağlık harcaması yaptığını ve sağlıklı olmak için diğer kuşağa göre davranış değişimini daha kolay gerçekleştirebilecekleri görülmektedir. Bu kuşağın sağlıklı kalmak ve daha genç görünmek amacı ile yaşlanma 
Dilşad ÇOKNAZ | Meftune ÖZBAKIR UMUT | Meltem NURTANIŞ VELIOĞLU

süreçlerinde, sağlık programlarını ve ürünlerini daha fazla talep etmeleri söz konusudur (Quine ve Carter, 2006, s.4).

\section{1. Çalışmanın Amacı}

Türkiye'deki B.B.K.'ların fiziksel aktivite açısından yetersizliği (Türkiye Fiziksel Aktivite Rehberi, 2014), önceki kuşağa göre daha uzun yaşlıık dönemi geçirecekleri öngörüsüne bağlı olarak sağlıklarına daha fazla dikkat etmeleri gerektiğine yapılan vurgu (Stein ve Potkanowicz, 2003), daha iyi yaşam koşullarına ve sağıklı yaşam tarzına sahip olmalarından kaynaklı önceki kuşağa göre daha uzun yaşayacakları öngörüsü (Oh ve Reeves, 2014; Black vd., 2013) ve Türkiye'nin giderek yaşlanan profili (TÜiK, 2013) B.B.K.'nı kamu sektörünün ve özel sektörün sunacağı sağlık hizmetleri açısından büyük bir pazar potansiyeli konumuna taşımaktadır.

Bu bağlamda, Türkiye'deki B.B.'larda sağlıklı yaşamın temel belirleyicilerinden biri olan fiziksel aktiviteyi yaygınlaştırmaya yönelik bir sosyal pazarlama programı geliştirilmesi sürecinde, Egzersiz Davranış Değişim Basamakları Modeli (E.D.D.B.M.)'ni kullanarak B.B.K.'ndan oluşan hedef kitleyi bölümlere ayırmak ve bu bölümlerin fiziksel aktiviteye yönelik algılanan fayda, engeller ve motivasyon öğelerini belirleyerek hedef kitle haritası çıkarmak temel alınmıştır. Çalışmanın amacı, bu doğrultuda belirlenen hedef kitle haritasına dayanarak B.B.K. için fiziksel aktivite içerikli bir sosyal pazarlama programı temelinde önerilerde bulunmaktır. Bu amaç doğrultusunda araştırmada yanıt aranan sorular şu şekilde belirlenmiştir:

1. B.B.K. egzersiz davranış değişim basamaklarının (E.D.D.B.) hangi aşamasındadır?

2. E.D.D.B.'nın eğilim öncesi, eğilim, hazırlık, hareket ve devamlıık basamaklarındaki bireylerin fiziksel aktiviteye yönelik algıladıkları engeller, faydalar ve motivasyon öğeleri nelerdir?

3. E.D.D.B.'nın farklı basamaklarına yönelik algılanan engel, fayda ve motivasyon öğelerini kapsayacak hedef kitle haritasına göre fiziksel aktivite içerikli bir sosyal pazarlama programı için neler önerilebilir?

\section{Yöntem}

Bu çalışma; nicel ve nitel yöntemlerin birlikte yer aldığı karma yöntem araştırmasıdır. Araştırmada "açımlayıcı desen" kullanılmıştır. Açımlayıı (exploratory) desen, araştırmacının nicel bir aşamayı yöneterek başladığı araştırmada, ikinci bir nitel araştırma aşaması ile özel sonuçlar aramayı amaçladığı karma yöntem desenidir (Creswell, 2014). Bu desende nicel aşamayı takip eden nitel aşama, ilişkili sonuçları daha derin açıklama amacıyla uygulanır ve desene adını veren de bu bulguları açıklamaya odaklanmadır. Bu desene "nitel takip yaklaşımı" da denilmektedir (Morgan, 1998; aktaran Creswell, 2014). Önce araştırmanın nicel bölümü gerçekleşmekte ve bu bölümde elde edilen sonuçlara göre nitel araştırma kısmı başlamaktadır (Yıldırım ve Şimşek, 2013). Bu desen çerçevesinde araştırmada nicel yaklaşım B.B.K.'nın E.D.D.B.'nin hangi aşamasında olduğunu belirleyerek pazar bölümlerini tanımlamak üzere kullanılmış ve araştırma bu pazar bölümlerinde fiziksel aktiviteye yönelik algılanan engel, fayda ve motivasyon öğelerinin derinlemesine analiz edilmesi amacıyla nitel yaklaşım ile devam etmiştir. 


\subsection{Ana kütle ve Örneklem}

Araştırma deseni doğrultusunda nicel aşama için araştırmanın ana kütlesi, Bolu il merkezinde yaşayan 174.687'lik toplam nüfusun 20.700'unu (TÜiK, 2013) oluşturan 1943-1960 doğumlu B.B.K. (Oh ve Reeves, 2014) olarak saptanmıştır. Baş (2001)'ın örneklem büyüklüğü formülüne göre; $\mathrm{n}=\mathrm{Nt^{2 }} \mathrm{pq} / \mathrm{d}^{2}(\mathrm{~N}-1)+\mathrm{t}^{2} \mathrm{pq}$

Formülde;

$\mathrm{N}$ : Hedef kitledeki birey sayısı

n:Örnekleme alınacak birey sayısı

p: Incelenen olayın görülüş sıklığı (gerçekleşme olasılı̆̆ı)

q: İncelenen olayın görülmeyiş sıklığı (gerçekleşmeme olasılığı)

t: belirli bir anlamllık düzeyinde, $\mathrm{t}$ tablosuna göre bulunan teorik değer

d: Olayın görülüş sıklı̆ı̆na göre kabul edilen \pm örnekleme hatasıdır.

Araştırma için kabul edilen anlamlılık düzeyi yüzde 95'dir. Bu anlamlılık düzeyinde z tablo değeri 1,96'dır. Sonuçlar yüzde 95 güvenilirlik aralığında, 0,05 örneklem hatası içerebileceği kabul edilmektedir. Ana kütlede ulaşılması gereken örneklem büyüklüğü ise en az 377 olarak hesaplanmış ve çaıışmanın bu aşaması 393 kişi ile gerçekleştirilmiştir.

Araştırma deseninin ikinci aşamasında, E.D.D.B.'nin farklı basamaklarında yer alan B.B.'ların fiziksel aktiviteye yönelik algıladıkları engel, fayda ve motivasyon öğelerinin derinlemesine sorgulandığı nitel aşamada görüşme yapılan kişi sayısı 33 (21 kadın, 12 erkek)'tür. 33 kişinin belirlenmesinde nitel araştırmanın doğasına uygun olarak “aşırı veya aykırı durum” örneklemesi ile E.D.B.B.'nin farklı basamaklarını temsil edecek şekilde, sekiz kişi eğilim öncesi (dört kadın-dört erkek), altı kişi eğilim (üç kadın-üç erkek), altı kişi hazırlık (üç kadın-üç erkek), dört kişi hareket (tamamı kadın) ve dokuz kişi de devamlıık (altı kadın-üç erkek) aşamasında yer alanlardan seçilmiştir.

\subsection{Verilerin Toplanması}

Araştırma verileri anket ve yüz yüze görüşme yolu ile toplanmıştır. B.B.K.'ndan oluşan hedef kitlenin D.D.B.M ile bölümlere ayrılmasında orijinali Marcus ve Lewis (2003)'e ait, Türkçe geçerlik ve güvenirlik çalışması Cengiz, Aş̧̧ı ve İnce (2010) tarafından yapılan “Egzersiz Davranış Değişim Basamakları Anketi” (E.D.D.B.A.) kullanılmıştır. Dört maddeden oluşan E.D.D.B.A.'da maddelerin evethayır şeklinde yanıtlanmasıyla, bireyler "eğilim öncesi, eğilim, hazırlık, hareket ve devamlıık" olmak üzere beş ayrı egzersiz davranış basamağına ayrılmaktadır. Bu aşamada Bolu'daki B.B.K.'nın fiziksel aktivite davranışının hangi aşamasında olduğunu belirlemek ve her aşamayı bir pazar bölümü olarak tanımlayabilmek için 470 adet E.D.D.B.A. dağıtılmış ve 393'ü değerlendirilerek analiz edilmiştir.

Egzersiz Davranış Değişim Basamakları (E.D.D.B.) ile belirlenen pazar bölümlerinin derinlemesine analizi için veriler yüz yüze görüşme tekniği ile toplanmıştır. Yüz yüze görüşmede kullanılan sorular "Sağlıklı İnsanlar 2010 Projesi (ABD)-Fiziksel Aktivitenin Yaygınlaştııılması Rehberi” (U.S. Depart- 
ment of Health and Human Service, 1999) doğrultusunda hazırlanmıştır. Görüşmelerde eğilim öncesi, eğilim ve hazırlık bölümlerinde olanlarının fiziksel aktiviteye yönelik algıladıkları engeller (neden fiziksel aktiviteye katılmadıkları vb.) ve faydalar (fiziksel aktivitenin sağladığı faydalar vb.), hareket ve devamlılık bölümlerinde olanların ise fiziksel aktiviteye yönelik algıladıkları faydalar ve motivasyonlarının (neden fiziksel aktiviteye katıldıkları vb.) ne olduğunun anlaşılması amaçlanmıştır. Bu doğrultuda görüşmeler, hareket ve devamlılık bölümlerinde yer alanlar ile dokuz, diğerleri ile sekiz soru kapsamında gerçekleştirilmiştir. Görüşmeler yarı yapılandırılmış olup, görüşmelerde tüm pazar bölümlerine yönelik ortak sorular olmakla beraber, hareket ve devamlılık bölümleri için "Siz fiziksel aktivite yapıyor musunuz? Neden?"; Fiziksel aktivite yaptığınızda ne tür faydalar elde ediyorsunuz? Anlatır mısınız?"; diğer pazar bölümleri için "Fiziksel aktiviteye yapamıyorsanız bunun nedenleri nedir? " gibi farklı sorular da yer almıştır. Görüşmeler katılımcıların kendilerini rahat hissedilecekleri bir ortamda, kendi istedikleri gün ve saatte gerçekleştirilmiştir. Görüşmelerde katılımcıların izni ile ses kayıt cihazı kullanılarak veriler kaydedilmiş, Creswell'in önerdiği şekilde (Creswell, 2009:183) ses kaydı ile birlikte araştırmacı tarafından notlar tutulmuştur.

\subsection{Verilerin Çözümlenmesi}

E.D.D.B.A. ile elde edilen veriler üzerinde betimsel istatistik (yüzde ve frekans dağılımı) analizleri SPSS 16.0 ile kullanılarak yapıımıştır. Görüşmelerden elde edilen veriler için içerik analizi kullanılmıştır. Öncelikle bilgisayar ortamında düz yazı haline getirilen veriler MAXQDA 11 nitel veri analizi programına aktarıımıştır. Bu aşamadan sonra kodlamalar biri MAXQDA 11 programı ile olmak üzere üç araştırmacı tarafından ayrı ayrı yapılmıştır. Yapılan kodlamaların karşılaştııılması ve ortak kodların oluşturulmasının ardından E.D.D.B.A. ile belirlenen her bir bölümün fiziksel aktiviteye yönelik algıladığı fayda ve engeller ile motivasyon öğeleri için hedef kitle haritaları oluşturulmuştur.

\subsection{Geçerlik ve Güvenirlik}

Araştırmada kullanılan E.D.D.B.A. Türk yetişkin popülasyonu için geçerliği ve güvenirliği kanıtlanmış bir ankettir. Karma yöntem araştırması ile gerçekleştirilen bu araştırmada geçerlik ve güvenirliği sağlayan önemli öğelerden biri de yöntem çeşitlemesinin (Tobin ve Begley, 2004; Briller, Meert, Schim ve Thurston, 2008; Bekhet ve Zauszniewski, 2012) kullanılmış olmasıdır. Bu doğrultuda veriler anket ve yüz yüze görüşme ile toplanmıştır. Ayrıca araştırmanın nitel aşamasında araştırmacıların yaptığı kodlamalar arasındaki tutarlıı̆ı̆ı hesaplanmasında Miles ve Huberman'ın (1994) güvenirlik formülü kullanılarak, güvenirlik korelasyonu yüzde 74 bulunmuştur. Güvenirlik hesaplamalarının yüzde 70'in üzerinde çıkması araştırmanın güvenirliği için geçerli orandır (Miles ve Huberman, 1994). Araştırma için Abant İzzet Baysal Üniversitesi İnsan Araştırmaları Etik Kurulu Başkanlığı'ndan izin alınmıştır.

\section{Bulgular}

Araştırmadan elde edilen bulgular iki bölümde sunulmuştur. Illk bölümde hedef kitleyi oluşturan B.B.K.'nın demografik özelliklerine ve E.D.D.B.A.'ya ait bulgular, ikinci bölümde ise E.D.D.B.A. ile belirlenen pazar bölümlerinin fiziksel aktiviteye yönelik algıladı̆̆ı fayda ve engeller ile motivasyon öğelerine ait bulgular yer almaktadır. 


\subsection{B.B.K.'nın Demografik Özelliklerine ve E.D.D.B.A.'ya İlişkin Bulgular}

Yaş ortalaması 62,03'den oluşan B.B.K.'nın yüzde 53,4'ü kadın, yüzde 46,6'sı erkek olup, yüzde 50,9'u 2001 TL. ve üzeri kazanca sahiptir. Eğitim durumuna göre B.B.K.'ın yüzde 29,5'i ilkokul, yüzde 26,2'si lisans ve yüzde 25,7'si lise mezunudur. B.B.K.'nın E.D.D.B.'na ait dağılımı ise Tablo 1'de gösterilmektedir.

Tablo 1. Katılımcıların Egzersiz Davranış Değişim Basamaklarına Ait Yüzde ve Frekans Dağıımı

\begin{tabular}{lcl}
\hline \hline E.D.D.B & Frekans & Yüzde \\
\hline Eğilim Öncesi & 156 & 39,7 \\
Eğilim & 54 & 13,7 \\
Hazırlık & 45 & 11,5 \\
Hareket & 26 & 6,6 \\
Devamlılık & 112 & 28,5 \\
Toplam & 393 & 100 \\
\hline
\end{tabular}

E.D.D.B.A. sonuçlarına göre B.B.K.'nın yüzde 39,7'sinin fiziksel aktivite davranışının eğilim öncesi, yüzde 13,7'sinin eğilim, yüzde 11,5'inin hazırlık, yüzde 6,6'sının hareket ve 28,5'inin de devamlılık aşamasında olduğu görülmüştür. Bulgular katılımcıların egzersiz davranış değişim basamaklarına göre iki farklı uç olan, yüzde 39,7 ile eğilim öncesi ve yüzde 28,5 ile devamlılık aşamasında olduğunu göstermektedir (Tablo 1).

\subsection{Sağıkı Yaşam Koşullarına Ait Bulgular}

E.D.D.B'nin her bir farkıı basamağında yer alan katılımcıların sağlıklı yaşam koşullarına ait kod haritalarına bakıldığında (Şekil 1., Şekil 2., Şekil 3., Şekil 4. ve Şekil 5.) en önemli iki koşulun dengeli ve düzenli beslenmek ve fiziksel aktivite yapmak olduğu anlaşılmaktadır. Bununla birlikte kötü alışkanlıklardan uzak durmak tüm pazar bölümlerinin ortak görüş bildirdiği bir koşul olmuştur. Hareket aşamasındakiler hariç diğer pazar bölümlerinde yer alanlar için stresten uzak kalmanın önemli olduğu anlaşılmaktadır. Uykunun önemli bir sağlıklı yaşam koşulu olarak algılanması hareket ve eğilim öncesi haricinde gerçekleşmiştir. Bunun dışında devamlılık, eğilim ve eğilim öncesinde yer alanlar için okumak, sağlıklı yaşamın öncelleri arasında görülmektedir. Hareket ve eğilim aşamasındakiler seyahat etmeyi, eğilim ve eğilim öncesi aşamadakiler düzenli sağlık kontrolü yaptırmayı sağ|ıklı yaşamın koşulları olarak bildirmişlerdir. Bunun dışında farklı aşamalarda müzik dinleme, sosyalleşme, hobi edinme ve kişisel bakım gibi etkenlerden de bahsedildiği görülmektedir. 


\section{Dilşad ÇOKNAZ | Meftune ÖZBAKIR UMUT | Meltem NURTANIŞ VELIOĞLU}

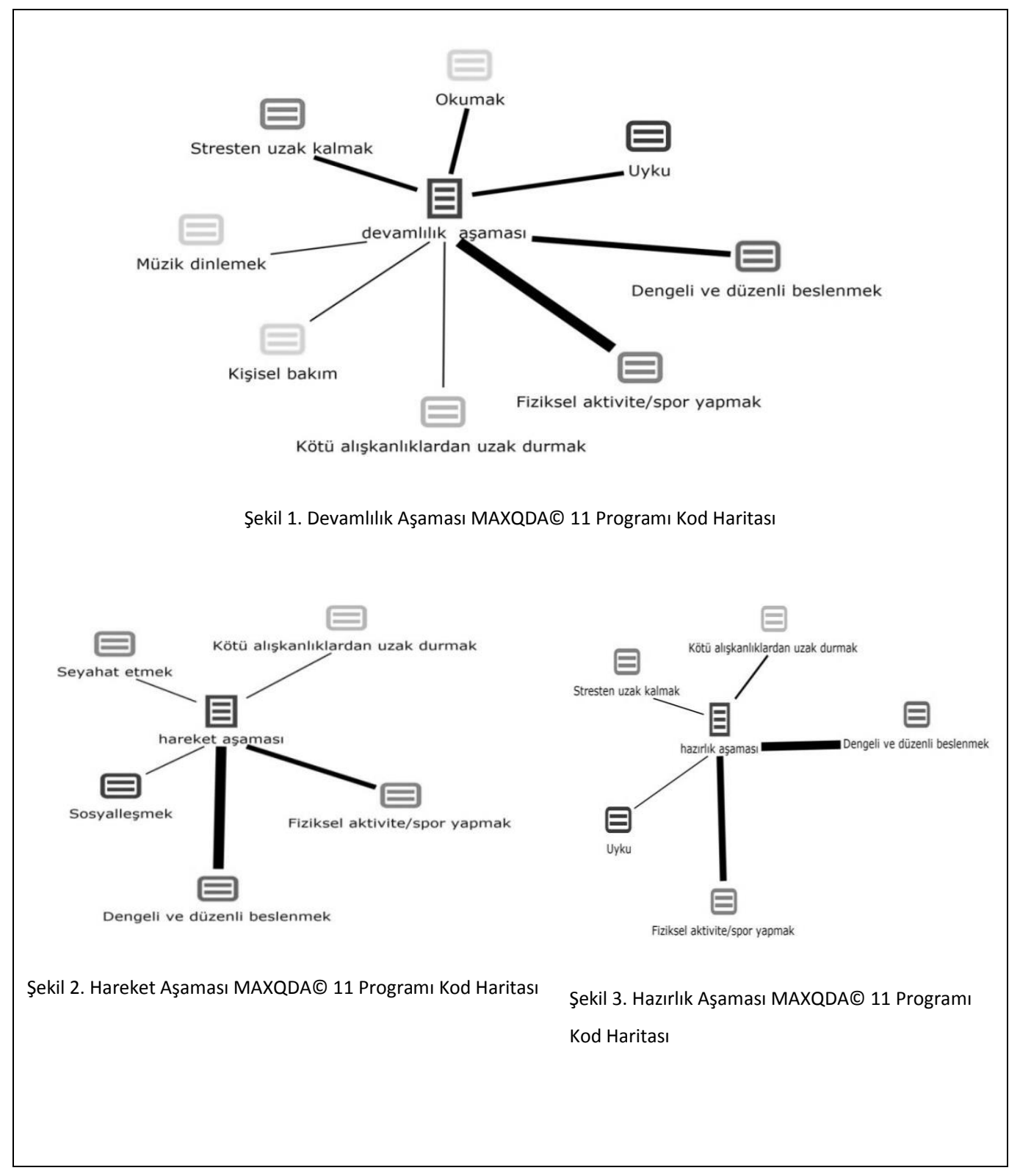




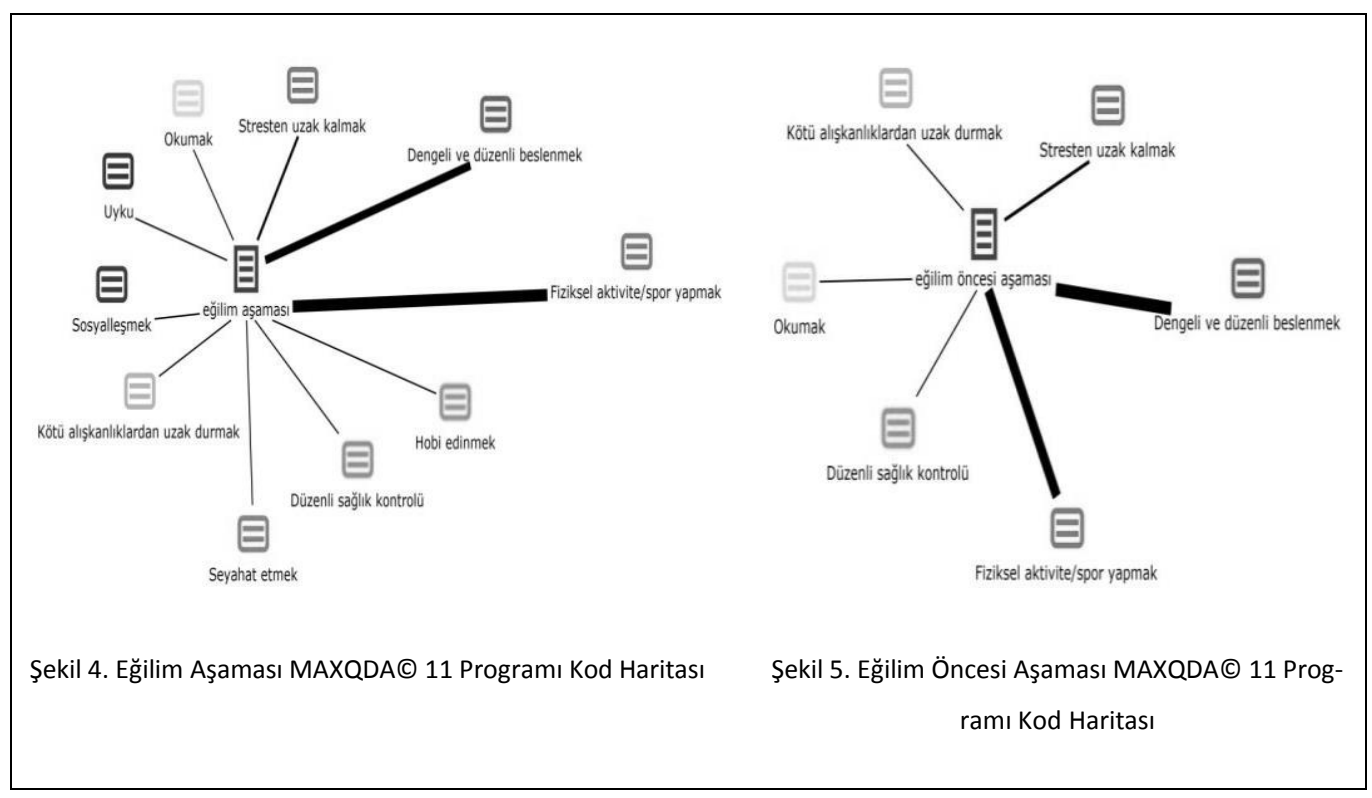

\subsection{Hareket ve Devamlıık Aşamasında Fiziksel Aktiviteye Yönelik Algılanan ve Beklenen Fayda ile Motivasyona Ait Bulgular}

Araştırmada E.D.B.B.'nın hareket ve devamlıı aşamasında olanlar altı aydan az veya daha fazla bir süredir fiziksel aktivite yapan pazar bölümlerini ifade etmektedir. Dolayısıyla bu bölümlerde yer alan katılımcıların fiziksel aktiviteden bekledikleri fayda ile birlikte elde ettikleri faydalar, ayrıca bu kişileri fiziksel aktivite yapmaya motive eden etkenlerin neler olduğu sorgulanmıştır. Şekil 6.'da gösterilen kod haritasında devamlılık aşamasındakilerin algıladıkları fayda ve fiziksel aktivite motivasyonları yer almaktadır. 


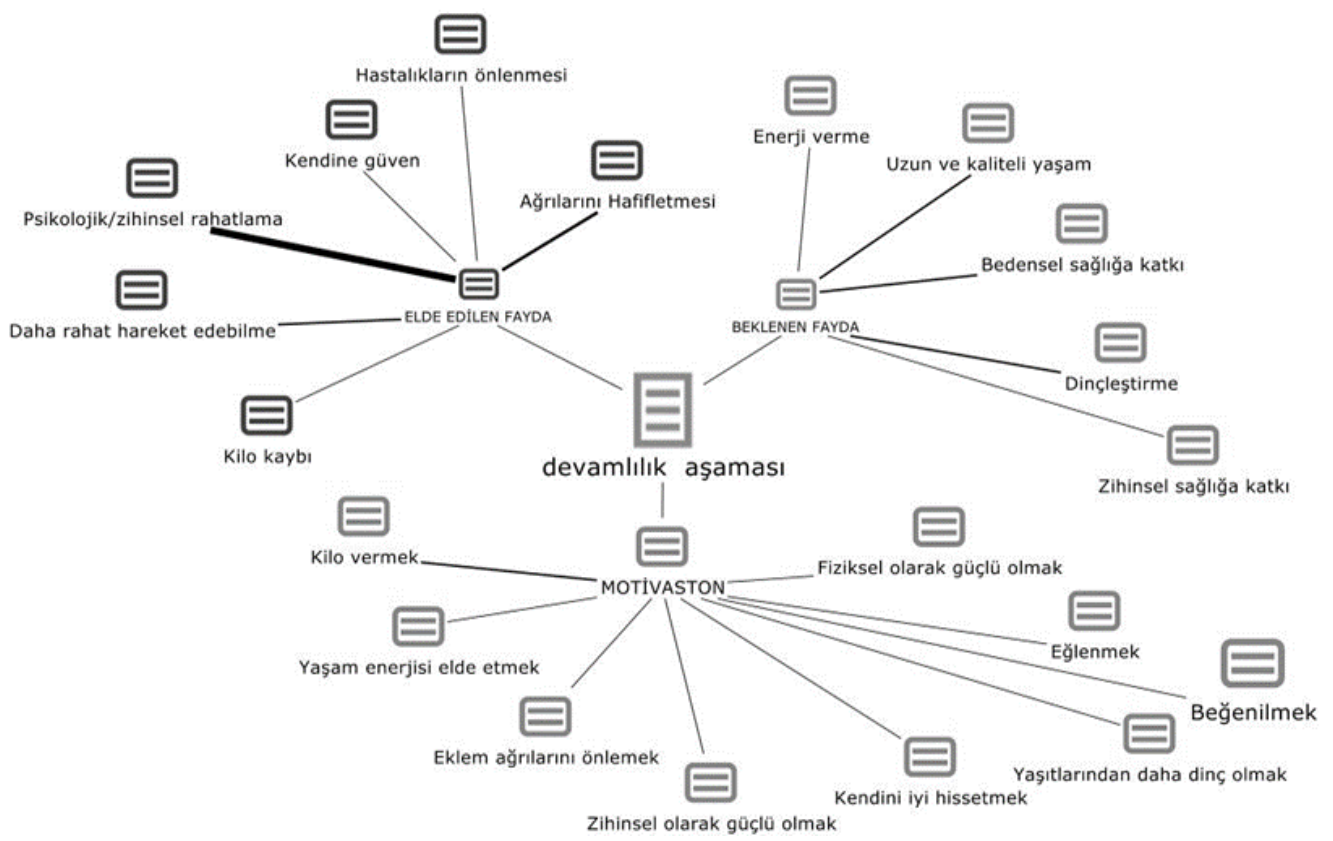

Şekil 6. Devamlııık Aşaması MAXQDAC 11 Programı Kod Haritaları

Şekil 6.'daki kod haritasına bakıldığında devamlılık aşamasındakilerin oluşturduğu pazar bölümünde fiziksel aktiviteden beklenen faydaların uzun ve kaliteli yaşam, dinçleşme ve bedensel sağlığa katkıda yoğunlaştığı anlaşılabilir. Elde edilen faydada ise öne çıkan konu açık bir şekilde psikolojik/zihinsel rahatlama olmuştur. Bunu takiben ağrıların hafiflemesi ve daha rahat hareket edebilme gibi fiziksel faydalar ortaya çıkmaktadır. Kod haritası bu aşamadakilerin neden fiziksel aktiviteye katıldıklarını gösteren motivlerde kilo vermenin öne çıktığını göstermektedir (Şekil 6.)

Şekil 7.'de yer alan kod haritasına göre hareket aşamasında açık bir şekilde öne çıkan beklenen fayda olmamakla birlikte, kilo kaybetme, hareketsizliği önleme ve şeker hastalığını tedavi etme gibi faydalara odaklanıldığı görülmektedir. Fiziksel aktiviteye katılım sonucu elde edilen faydalarda ise devamlılık aşamasındakilerde olduğu gibi psikolojik rahatlama öne çıkmakta ve bunu fiziksel rahatlama takip etmektedir. Hareket aşamasındakileri fiziksel aktiviteye yönlendiren en önemli motivasyon öğesi ise hastalanmaktan korkmaktır. 


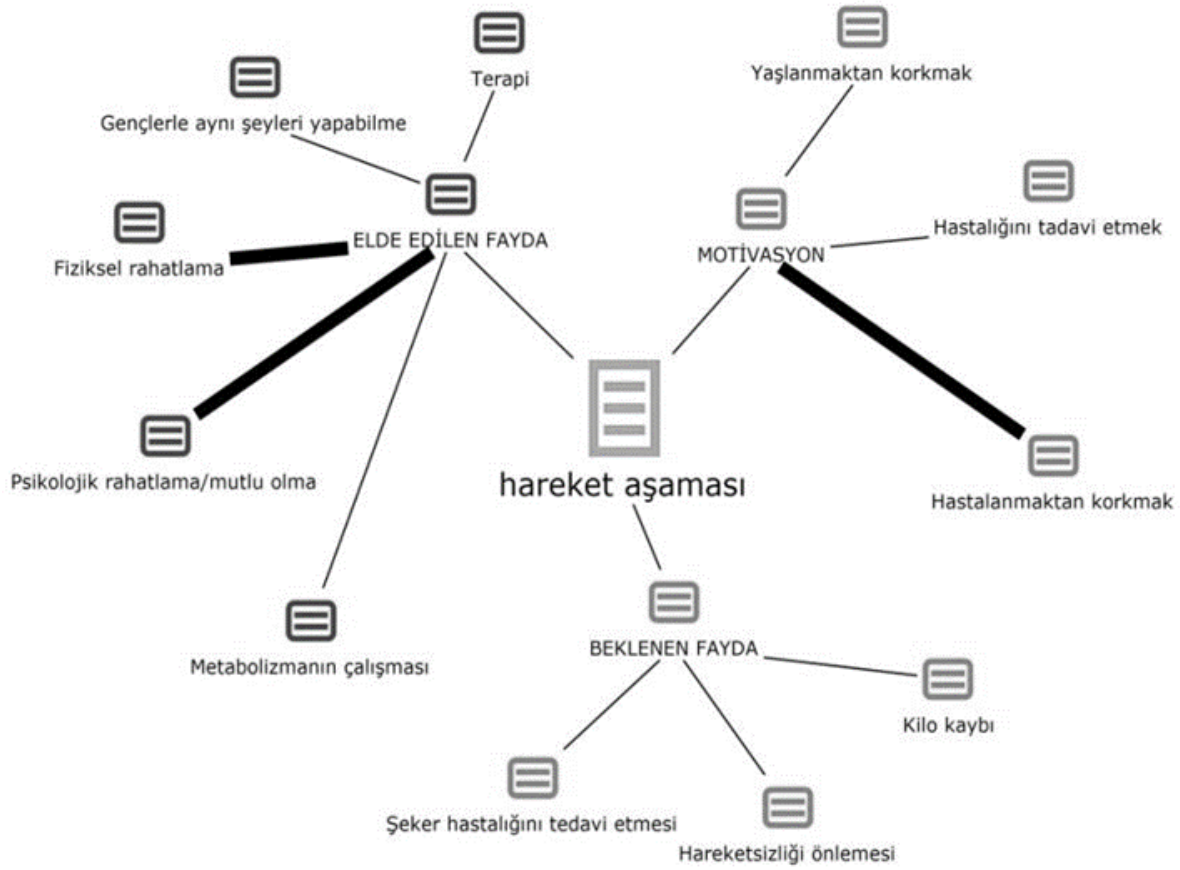

Şekil 7. Hareket Aşaması MAXQDAC 11 Programı Kod Haritaları

\subsection{Hazırlık, Eğilim ve Eğilim Öncesi Aşamada Beklenen Fayda ile Algılanan Engellere Ait Bul- gular}

E.D.B.B.'nin hazırlık aşaması fiziksel aktiviteye yönelik çok yakın bir zamanda, örneğin gelecek ay içinde harekete geçmeye yönelik güçlü niyet taşındığını gösterirken, eğilim ve eğilim öncesi aşama son altı aydır fiziksel aktivite yapmayan pazar bölümlerini ifade etmektedir. Fiziksel aktivite davranışının sergilenmediği bu pazar bölümlerinde, fiziksel aktiviteden beklenen faydalar ile birlikte bireyleri fiziksel aktivite yapmaktan alıkoyan engellere odaklanılmıştır.

Öncelikle hazırlık aşamasındakilerin fiziksel aktiviteden solunum sistemini güçlendirmesi ve esneklik gibi fiziksel kazanımlar, zihinsel rahatlama ve psikolojik destek gibi psikolojik kazanımlar bekledikleri anlaşıımaktadır (Şekil 8.). Bu aşamadakilerin fiziksel aktiviteye katılmamaları yönündeki engellerin en yoğundan en aza doğru zaman, iklim ve tek başına yapmanın sıkıcı olması şeklinde sıralandığı görülmektedir. 


\section{Dilşad ÇOKNAZ | Meftune ÖZBAKIR UMUT | Meltem NURTANIŞ VELIOĞLU}

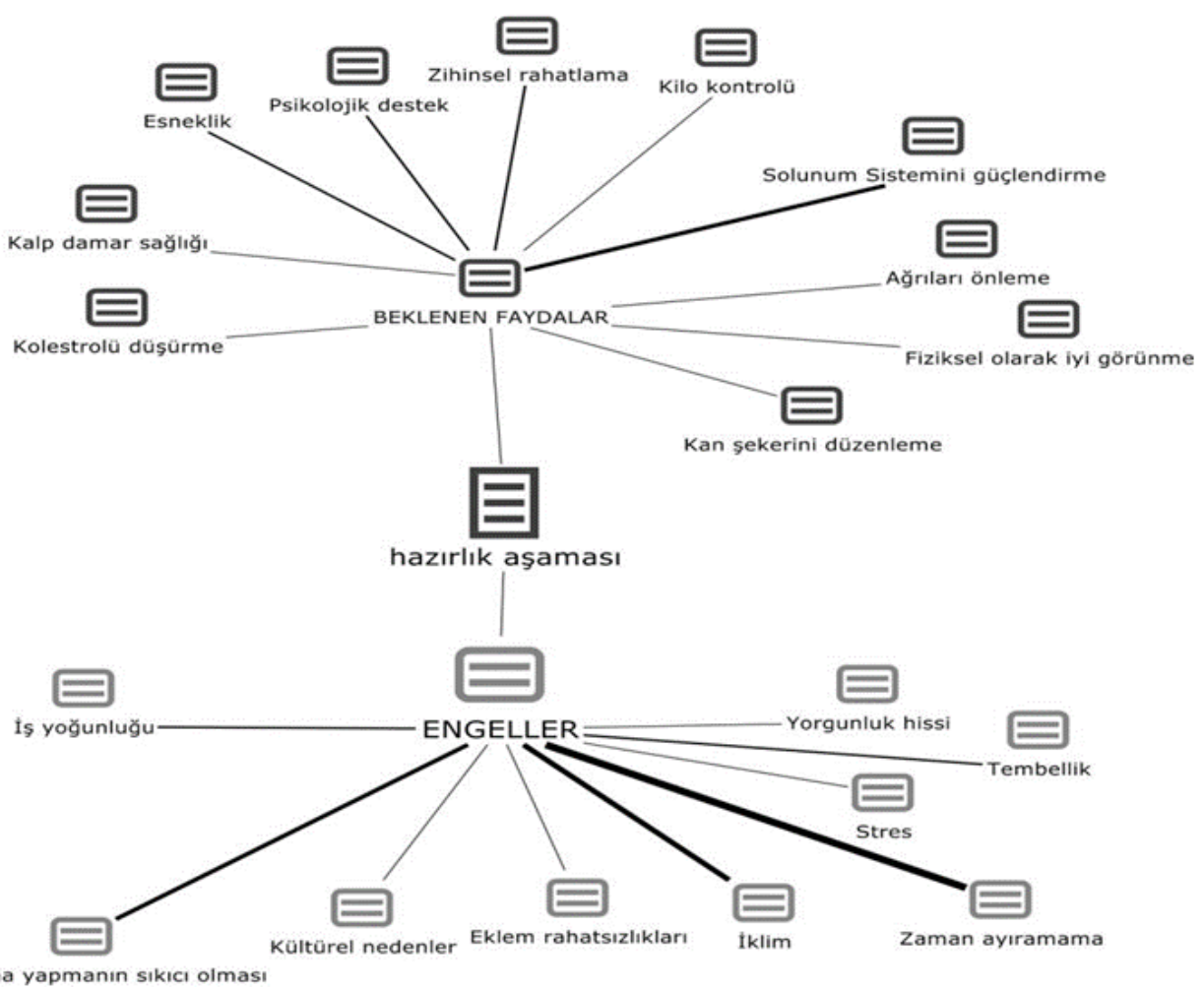

Şekil 8. Hazırlık Aşaması MAXQDA@ 11 Programı Kod Haritaları

Şekil 9.'da eğilim aşamasına ait beklenen fayda ve algılanan engeller yer almaktadır. Bu aşamada beklenen en önemli fayda fiziksel aktivitenin psikolojik sağlığa olan katkısıdır. Engeller arasında ise bireylerin sağlık sorunlarından dolayı fiziksel aktivite yapamaması ve iklim daha öncelikli görünmektedir. 


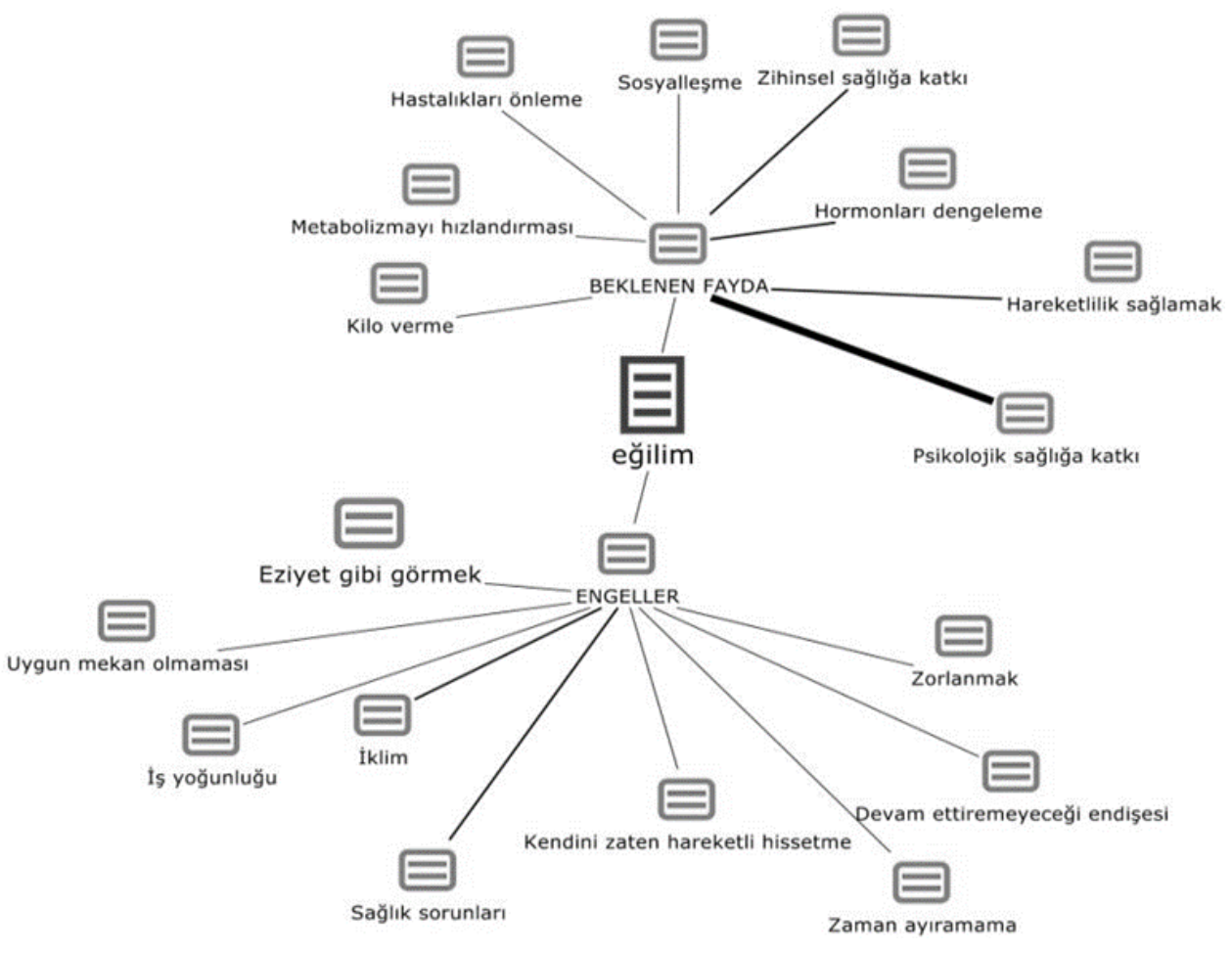

Şekil 9. Eğilim Aşaması MAXQDAC 11 Programı Kod Haritaları

Eğilim öncesinden oluşan pazar bölümündekiler fiziksel aktiviteden en fazla kas-iskelet sistemini güçlendirme gibi bir fayda beklemektedir. Eğilim öncesindekilerin kod haritası (Şekil 10.) beklenen faydaların daha çok fiziksel sağlığa ilişkin olduğuna işaret etmektedir. Bu pazar bölümünde katılımı etkileyen en önemli engeller ise zaman, mekân, sağlık sorunları ve tek başına yapmanın sıkıcı olması şeklinde belirginleşmektedir. 


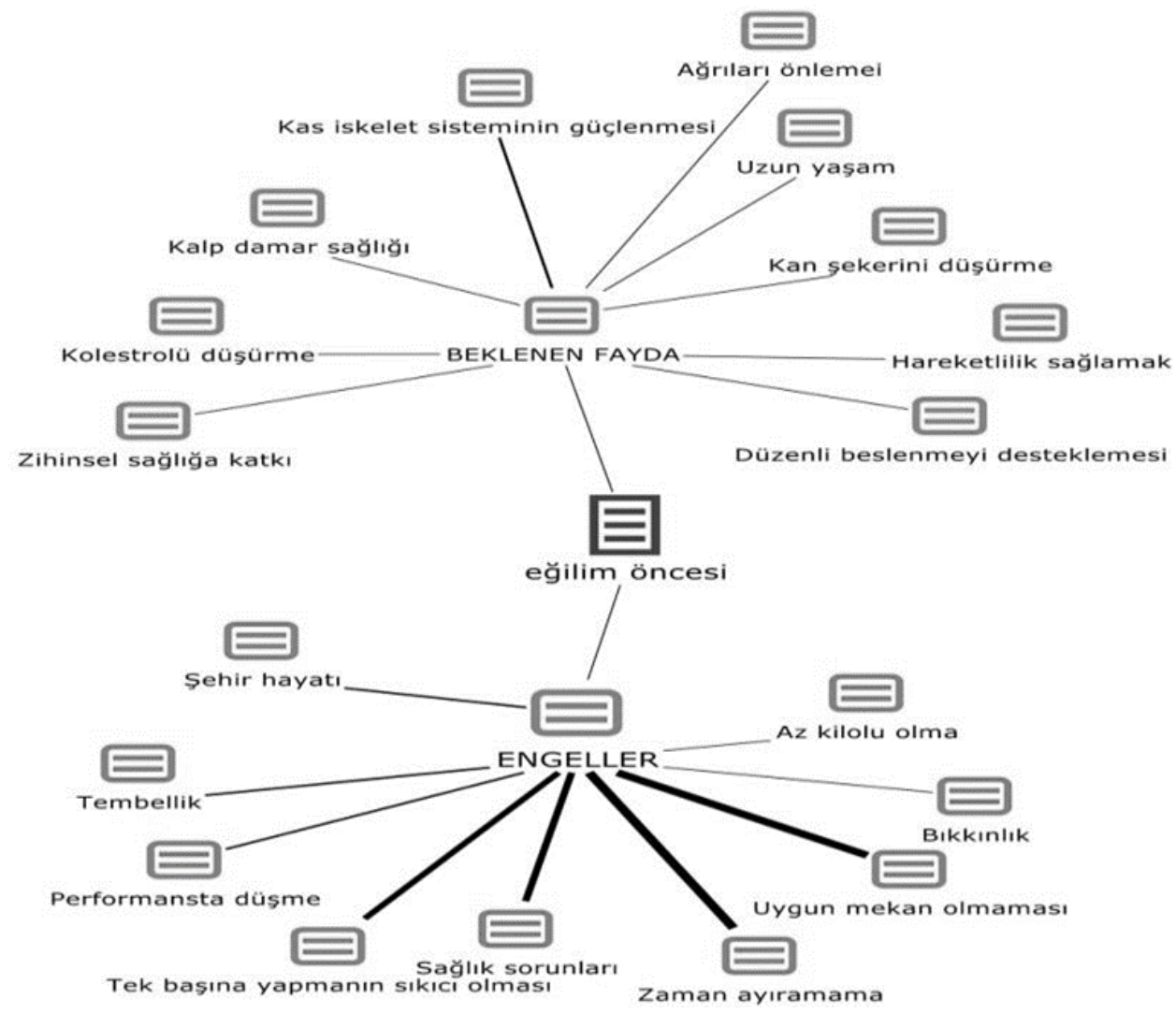

Şekil 10. Eğilim Öncesi MAXQDAC 11 Programı Kod Haritası

\section{Tartışma}

Araştırma sonuçları hedef kitlenin "eğilim öncesi, eğilim, hazırlık, hareket ve devamlılık basamakları" olarak bölümlendiğinde, "eğilim öncesi" ve "devamlılık" bölümlerinde yoğunlaşma olduğunu göstermektedir. Farklı toplumlarda D.D.B.M. temelinde yapılan çalışmalarda benzer sonuçlar görülebilmektedir. Örneğin yüzde 20 'sini 60 yaş ve üstünün oluşturduğu Brezilyalı yetişkinlerin, fiziksel aktivite davranış düzeylerinin belirlendiği çalışmada, popülasyonun iki uç olan, eğilim öncesi (yüzde 38,3) ve devamlılık (yüzde 24) aşamalarında yoğunlaştığı görülmüştür (Dumith, Gigante ve Domingues, 2007). D.D.B.M. ile iki uca dağılımın tespit edildiği bir başka çalışma ise yaş ortalaması 69,93 olan Yunan bireyler ile ilgili olup, bu bireylerin yüzde 46,2'sinin eğilim öncesi, yüzde 23.3'ünün de devamlıık aşamasında olduğu görülmektedir (Thøgersen-Ntoumani, 2009). D.D.B.M.'de davranışın istenen düzeyde varlığını gösteren aşama devamlııık ve davranışın zaman zaman gözlenebildiği aşama da harekettir. Bunlar dışındaki aşamalarda ise davranış istenen düzeyde değildir ve çoğu zaman hiç gözlenemez. Dolayısıyla fiziksel aktivite davranışı açısından araştırmanın hedef kitlesi, bu yaş 
grubunda kardiyovasküler sağlık açısından fiziksel aktiviteden istenen faydanın sağlanabileceği “haftada en az 150 dakika orta yoğunlukta", sağlıkla ilgili diğer faydaların elde edilebileceği "haftada en az 300 dakika orta yoğunlukta" aktivite ilkesinin (Dünya Sağlık Örgütü, 2016) uzağında kalmaktadır. Türkiye genelinde yetişkinlerin fiziksel aktiviteye katılımının yetersiz düzeyde olduğu (Türkiye Fiziksel Aktivite Rehberi, 2014) düşünüldüğünde de araştırma grubu bir anlamda Türkiye profilini yansıtan özellik taşımaktadır. Yaş ile beraber hareketsizliğin arttığına yönelik uyarılar (Türkiye Fiziksel Aktivite Rehberi, 2014) ile birlikte, bu araştırmanın E.D.D.B.M. aşamasından elde edilen sonuçlar birlikte ele alındığında, B.B.K.'dan oluşan hedef kitlenin oldukça hareketsiz bir yaşam tarzı ile fiziksel aktiviteye yönlendirilmesi gereken öncelikli gruplardan biri olduğu bir kez daha kanıtlanmıştır. Devamlılık aşamasındakilerin ikinci sırada yer alması bu çalışmanın sevindirici sonuçlarından biridir. Çünkü bu sonucun B.B.K.'nın yaşlandığında mevcut yaşam tarzını devam ettirebilmek için daha sağlıklı olmada davranış değişimini kolay gerçekleştirebilme (Quine ve Carter, 2006) potansiyeline sahip olduğunun göstergesi sayılabilir.

Sosyal pazarlamada rekâbeti güçlendirmek için Kotler vd.'nin (2002) “değişime en hazır olan hedef kitleyle başlayın" önerisinden hareketle başlayan bu çalışmanın devamı, yine sosyal pazarlama çalışmalarında önemle vurgulanan, bireylerin davranış değişim aşamalarının belirlenmesinden sonra davranışa ilişkin algı, tutum ve motivasyonlarının bilinmesi ilkesi ile devam etmiştir. Çünkü sosyal pazarlama, hedef kitlenin davranış değişiminin hangi basamağında olduğunu anlamayı, her bir farklı davranış değişim basamağına, farklı stratejiler ile yaklaşılması gerekliliğini önemser. Bu ilke temelinde Avustralya'da yaşayan ileri yaşılıardan oluşan hedef pazarda, astım hastalığının farkındaığını arttırmak amacı ile geliştirilen bir sosyal pazarlama programının ilk aşamasını hedef pazarı bölümlere ayırma, her bölümü birbirinden ayıran özellikleri belirlemeye odaklandığı ve çalışmanın sonucunda geliştirilen mesajlara her bir bölümün farklı tepkiler verdiği görülmüştür (Evers, Jones, Iverson ve Caputi, 2013, s.1).

Mevcut çalışma B.B.K'nı E.D.D.B. ile bölümlere ayırdıktan sonra her bölümün davranışla ilgili özelliklerini incelemeyi temel almıştır. Araştırma sonuçları E.D.D.B'nin tüm basamaklarında, fiziksel aktivite ve dengeli ve düzenli beslenmenin sağ lıklı yaşamın en önemli iki belirleyicisi olduğunu göstermektedir. Bu bağlamda aslında tüm pazar bölümlerinin sağlıklı yaşam konusunda bilgi düzeyi yüksektir. Wilson'a (2002) göre de B.B.'lar sağlıklı yaşamın ne olduğu ve fiziksel aktivitenin sağlıklı yaşamdaki önemi hakkında bilgi sahibidir (Akt: Swan, Friis ve Turner, 2008). Dünya Sağlık Örgütü'nün toplum sağlığı çalışmalarındaki öncelikli iki konusu düzenli beslenme ve fiziksel aktivite olup (www.who.int/chp/about/en/), sigara içmeme, az alkol tüketme, zihinsel etkinlikler, sosyalleşme, açık havada bulunma ve olumlu düşünme gibi konular da (ww.medic8.com/healthguide/elderlycare/healthy-lifestyle.html) sağlıklı bir yaşamın belirleyicileri olarak görülmektedir. Ancak insanların pek çok şeyi bilmelerine karşın onu yapma konusunda boşluğa düştükleri çok sayıda örnek bulunmaktadır. Bu yüzden bilgi, davranış değişikliği ile aynı biçimde değerlendirilmemelidir (www.des.nh.gov/organization/grant_outreach_guides.pdf). B.B.K.'nın fiziksel aktiviteyi sağlıklı yaşamın koşulu olarak görmesine karşın hedef kitlenin büyük bölümünün hareketsiz olması da aslında bu durumu açıklamaktadır. 
Dilşad ÇOKNAZ | Meftune ÖZBAKIR UMUT | Meltem NURTANIŞ VELIOĞLU

E.D.D.B. temelinde yine tüm pazar bölümlerinin fiziksel aktiviteden beklediği faydalar da benzerlik göstermektedir. Tüm pazar bölümlerinde beklenen faydalarda fiziksel ve psikolojik sağlığa yönelik olanlar oldukça belirgindir.

Fiziksel aktiviteden elde edilen faydalar yalnızca fiziksel aktivite yapan devamlılık ve zaman zaman fiziksel aktivite yaptığı söylenebilecek hareket bölümlerinde ele alınmıştır. Sosyal pazarlamada önerildiği üzere bu pazar bölümlerinin elde ettiği faydaların derinlemesine analizi yapıldığında bireylerin fiziksel aktiviteye katılım dolayısıyla elde ettikleri faydaların; psikolojik (rahatlama, kendine güven), fiziksel (hareketlilik, kilo kaybı) ve hastalığını tedavi etmeye yönelik olduğu anlaşılmıştır.

Devamlılık ve hareket aşamalarından oluşan pazar bölümlerinin fiziksel aktivite ile ilgili motivasyonları farklı çalışmalarda ortaya çıkan sonuçlar ile oldukça benzerlik göstermekle birlikte (Burton, Lewin ve Boldy, 2013; Cohen-Mansfield, Marx, ve Guralnik, 2003; Kolt, Driver ve Giles, 2004; Kirkby, Kolt, Habel ve Adams, 1999; Mathews vd., 2010; Sit, Kerr ve Wong, 2008) özellikle hareket aşamasında "hastalıkların tedavisi" yaklaşımı ile farklılaştığı anlaşılmaktadır.

Hazırlık, eğilim ve eğilim öncesi pazar bölümleri fiziksel aktiviteye katılım göstermeyen bölümleri oluşturmaktadır. Bu bölümlerde yer alanların fiziksel aktiviteye katılmamaları yönünde algıladıkları zaman, iklim, mekân, tek başına yapmanın sıkıcı olması gibi engeller genel olarak benzerlik göstermektedir. Bilindiği gibi hareketsizliğin ortaya çıkmasında, fiziksel aktivitenin önerilen ve istenilen düzeyde olmamasında, fiziksel aktiviteye katılımda algılanan engeller önemli bir sorun oluşturmaktadır. Yapılan araştırmalar incelendiğinde farklı toplumlarda da olsalar, bireylerin fiziksel aktiveye katılmama konusunda birbirine çok benzeyen engeller öne sürdükleri anlaşılmaktadır. B.B.'lar özelinde fiziksel aktivitede algılanan engellere bakıldığında 70 yaş üstü bireylerde yaralanma korkusunun, fiziksel aktivite için çok yaşlı olunmasının, iklimin ve maliyetlerin (Burton, Lewin ve Boldy, 2013) önemli olduğu görülmektedir. Sit, Kerr ve Wong (2008) fiziksel aktivite davranışının hazırlık, eğilim ve eğilim öncesi aşamalarında yer alan yaşlı bireylerin zaman, beceri eksikliği ve aile/arkadaş desteğinin olmaması gibi engeller algıladığını ortaya koymuştur. Cohen-Mansfield, Marx ve Guralnik (2003) ise 7485 yaş arası bireylerde en sık tekrarlanan engelin eklem ağrılarına dayalı sağlık problemleri olduğundan, bununla birlikte zamansızlık, hava koşulları ve üşenme/tembellik gibi engellerden de bahsetmektedir.

Araştırmadaki katılımcılar doğrudan kendilerine ait bir engel olarak bahsetmeseler de Türk toplumunda ilerleyen yaşlarda fiziksel aktivite yapanların nasıl göründügü ile ilgili değerlendirmelerinde kültürel bir engel algısının varlığına işaret etmiştir. "Bisiklete binmeyi düne kadar insanlar ayıp sanıyordu. Bizim yaştaki kaç insan bisiklete binip Bolu'da sokaklarda gezebiliyor hele ki bayanlar!". "Kayınpederim var 85 yaşında, bizden daha sağlam. Yürüyüş yapar, ilk yürümeye başladığı zaman bütün Bolu "bu deli" diye gülüyordu...". "Yaşımız ilerledikçe enerjimiz de azalıyor, istekler azalıyor. Kendimizi çekiyoruz koskocaman kadın oldun" gibi ifadeler engellerin kültürel nedenlere dayalı olarak farklılaştığını göstermektedir. 


\section{Sonuç ve Öneriler}

Sosyal pazarlamada pazar bölümlendirme ve hedef pazar seçimi ayrıcalıklı bir öneme sahiptir. Davranış değişimine odaklı yapısı ile sosyal pazarlama öncelikle her bir pazar bölümünün mevcut davranışlarını anlamaya çalışır. Seçilecek bölüm ya da bölümlerin özelliklerine göre pazarlama karması ve onlara uygun mesajlar geliştirilmesinin temelinde yer alan ana düşünce budur. B.B.K.'da fiziksel aktiviteyi yaygınlaştırmaya yönelik düzenlenecek sosyal pazarlama programlarının da bu doğrultuda bir yaklaşım sergilemesi hareketsizlik ile ilgili mücadelede etkili bir yol olarak düşünülmelidir. Sağlık ve fitness sektörünün pazarlama disiplinini kullanarak B.B.K.'yı harekete geçirmek için yalnızca mesajlara dayalı çözüm üretmeleri yeterli görünmemekte (Milner, 2005), alandaki profesyonellerin bu yaş grubunda yer alan bireylerin benzerlik ve farklılıklarına dayalı çözümler üretmesi daha önemli hale gelmektedir (Patel, Schofield, Kolt ve Keogh, 2013). Mevcut çalışma; sosyal pazarlama temelinde ve Türkiye özelinde ilk kez yapılan hedef kitlenin haritalama çalışması ile B.B.K'da yer alan bireylerin, fiziksel aktivite davranışı konusunda benzerlik ve farklııklarını ortaya koyarak, uygulamacılara ve karar yapıcılara hedef kitle seçiminde ışık tutma ve pazarlama stratejilerinin yapılandırılmasında alt yapı oluşturma yönünde katkı sağlayacaktır.

Sağlıklı olabilmenin temel koşullarından biri de fiziksel olarak aktif olmaktır. Dolayısıyla her yaş grubunda olduğu gibi B.B.ler de "yaşlarından başlarından utanmaksızın" ya da "unlarını eleyip eleği duvara asmaksızın" fiziksel aktiviteye katılmalıdır. Hazırık aşamasındakilerin niyetlerinin daha güçlü olması sebebiyle programlarda öncelikli grup olarak ele alınmaları düşünülmelidir. Tüm pazar bölümlerinin fiziksel aktivitenin yararları konusunda bilgi düzeyinin yüksek olması sebebi ile literatürde önerilenin aksine eğilim öncesi aşamadakilerde bilgilendirme çalışmaları yerine doğrudan davranışın denenebileceği ortamların yaratılması daha etkili sonuçlar yaratabilir. Çalışma sonuçlarına göre olumsuz kültürel algıları ortadan kaldıracak mesajların geliştirilmesi önerilmekte ve "Tek başına fiziksel aktivite yapmanın sıkıcı olması" engeline karşıık, görüşmeler sırasında ifade edilen "arkadaşlarla birlikte etkinlikler" seçeneğinin düşünülmesi gerekmektedir. Ayrıca fiziksel aktivite programlarının dengeli ve düzenli beslenme programları ile birlikte ele alınması ve programlarda verilecek mesajların gerçeklerden yola çıkarak, engelleri ortadan kaldırmaya ve motivasyonu güçlendirmeye yönelik olması gerekmektedir.

Sonuç olarak bu çalışma ile Türkiye'de B.B.K.'ın yapılan haritalama çalışması ile fiziksel aktivite davranışının farklı basamaklarında yer aldığı ve her bir basamağın kendi özelinde benzerlik ve farklılıklara sahip olduğu, oluşturulacak pazarlama stratejilerinin de bu temelde yapılandırılması gerektiği ortaya konulmuştur.

Araştırmanın kısıtları; B.B.K'nın erken ve geç dönemi ayrımını yapmamış olması, sadece Bolu ilinde ve kış döneminde gerçekleşmiş olmasıdır. Bu doğrultuda sosyal pazarlama kapsamında ilk kez yapılacak haritalamanın, Türkiye genelinde, B.B.K'nın erken ve geç dönemini ayırarak, farklı il ve mevsimlerde tekrarlanması önerilmektedir. 
Dilşad ÇOKNAZ | Meftune ÖZBAKIR UMUT | Meltem NURTANIŞ VELIOĞLU

\section{Kaynaklar}

Amerika Birleşik Devletleri İstatistik Kurumu. (2006). "Selected Characteristics of Baby Boomers 42 to 60 Years Old in 2006", Age and Special Populations Branch Population Division U.S. Census Bureau, Washington D.C., 1-46.

Arı, K. (1992). "Cumhuriyet Dönemi Nüfus Politikasını Belirleyen Temel Unsurlar”, Atatürk Araştırma Merkezi Dergisi, VIII (23).

Balcı, E. (2012). Yaşlı Sağlığı: Sorunlar ve Çözümler (ss.42-47). Ed. Aslan, D. Ertem, M., Halk Sağlığı Uzmanları Derneği. Erişim tarihi: 26.05.2016, http://halksagligiokulu.org.

Baş, T. (2001). Anket. Ankara: Seçkin Yayıncılık.

Bekhet, A.K. ve Zauszniewski, J.A. (2012). Methodological Triangulation: An Approach to Understanding Data. Nurse Researcher, 20 (2), 40-43.

Bertan, M. ve Özçebe,H. (1993). “Türkiye'de Nüfus ve Sağlık, Türkiye'de Nüfus Konuları”, Ed: Aykut Toros, , Hacettepe Üniversitesi Nüfus Etüdleri Enstitüsü (HÜNEE) Yayını, Ankara, 141-208.

Bilir, N. (2007). Yaşılııkta Kaliteli Yaşam, Hacettepe Üniversitesi Geriatrik Bilimler Araştırma ve Uygulama Merkezi. Erişim tarihi: 26.05.2016, www.gebam.hacettepe.edu.tr.

Black, D.A., Wilson, L.A., O'Loughlin, K., Noone,J., Kending, H., Butcher, B. (2013). Housing Type, Location Of Residence And Health Status in Australian Baby Boomers: Results From The Australian Baby Boomer (ABBA) Study. Australasian Journal on Ageing, 1-4, DOI: 10.1111/ajag.12119.

Bouck, C. (2013). The Future of Active-aging Adult Centers. The Journal on Active Aging, Special Developer's Issue, June, 46-51.

Briller, S.H., Meert, K.L.,Schim, S.M, Thurston, C.S. (2008). Implementing a Triangulatıon Protocol in Bereavement Research: a Methodological Discussion. Omega, 57 (3), 245-260.

Buchthal, O.V., Doff, A., Hsu, L., Silbanuz, A., Heinrich, K. ve Maddock, J. (2011). Avoiding a Knowledge Gap in a Multiethnic Statewide Social Marketing Campaign: Is Cultural Tailoring Sufficient? Journal of Health Communication, 16, 314-327.

Burton, E., Lewin, G. Ve Boldy, D. (2013). Barriers and Motivators To Being Physically Active For Older Home Care Clients. Physical and Occupational Therapy in Geriatrics, 31 (1), 21-36.

Cengiz, C., Aşçı, H. ve İnce, L. (2010). Egzersiz Davranış Değişim Basamakları Anketi: Geçerlik ve Güvenirlik Çalışması, Türkiye Klinikleri Journal of Sports Science, 2 (7), 32-7.

Cohen-Mansfield, J., Marx,M.S. and Guralnik, J.M. (2003). Motivators and Barriers to Exercise in an Older Community-Dwelling Population, Journal of Aging and Physical Activity, 11, 242253. 
Creswell, J. W. (2013). Nitel Araştırma Yöntemleri, Beş Yaklaşıma Göre Nitel Araştırma ve Araştırma Deseni, Çev. Ed. Bütün M. ve Demir, S. B. Ankara: Siyasal Kitapevi.

Creswell, J.W. (2009). Research Design: Qualitative, Quantitative and Mixed Methods Approaches. California: Sage Publications.

Crumpacker, M. ve Crumpacker,J.M. (2007). “Succession Planning and Generational Stereotypes: Should HR Consider Age-Based Values and Attitudes a Relevant Factor or a Passing Fad?", Public Personnel Management, 36(4), Winter, 349-369.

Doğan, L. (1993). “Türkiye Nüfusunun Kültürel, Dini ve Politik Özellikleri, Türkiye'de Nüfus Konuları”, Ed: Aykut Toros, Hacettepe Üniversitesi Nüfus Etüdleri Enstitüsü (HÜNEE) Yayını, Ankara, 209278.

Dollatabady, H. R., Amiri F., Bidmeshk, O. G. (2012). Using Social Marketing Principles to Describe Local Isfahan Managers' Attitude about Using New Energy Resources, International Joumal of Marketing Studies, 4 (3), 160-172.

Donovan, R.J., Paterson, D., Francas, M. (1999). Targeting Male Perpetrators Of Intimate Partner Vılence: Western Australia's "Freedom From Fear" Campaign, Social Marketing Quarterly, $5(3), 127-144$.

Dumith, S.C., Gigante D.P., and Domingues, M.R. (2007). Stages of Change for Physical Activity in Adults from Southern Brazil: A Population-based Survey, International Journal of Behavioral Nutrition and Physical Activity 4 (25), 1-10.

Dünya Sağlık Örgütü (2016). Erişim tarihi: 10.05.2016, http://www.who.int/dietphysicalactivity/factsheet_olderadults/en.

Evans, D. (2007). The 5-4-3-2-1 Go! Intervention: Social Marketing Strategies for Nutrition, Journal of Nutrition Education Behavior, 39, 55-59.

Evans, D. (2008). Social Marketing Campaigns and Children's Media Use, Social Marketing Quarterly, 18 (1), 181-203.

Evans, D., Christoffel K.K., Necheles J., Becker A.B., Snider J. (2011). Outcomes of The 5-4-3-2-1 Go! Childhood Obesity Community Trial, American Journal of Health Behavior, 35 (2), 189-198.

Evers, U., Jones, S. C., Iverson, D., Caputi, P. (2013). 'Get Your Life Back': Process And Impact Evaluation Of An Asthma Social Marketing Campaign Targeting Older Adults. BMC Public Health, 13 (759), 1- 12.

Fujihira, H., Kubacki, K., Ronto, R.,Pang B. and Rundle-Thiele S. (2015). Social Marketing Physical Activity Interventions Among Adults 60 Years and Older: A Systematic Review. Social Marketing Quarterly, 21(4), 214-229.

Güriz, A. (1971). "Türkiye'de Siyasi Partilerin Nüfus Politikası Konusunda Görüşleri”, Ankara Üniversitesi Hukuk Fakültesi Dergisi, 28 (1/4), 13-40. 
Dilşad ÇOKNAZ | Meftune ÖZBAKIR UMUT | Meltem NURTANIŞ VELIOĞLU

Helmig, B. ve Thaler, J. (2010). "On the Effectiveness of Social Marketing What Do We Really Know?", Journal of Nonprofit \& Public Sector Marketing, 22, 264-287.

Hogan, H., Perez, D. ve Bell,W..R. (2008). "Who (Really) are the First Baby Boomers?", Joint Statistical Meetings Proceedings, Social Statistics Section, Alexandria, VA: American Statistical Association, 1009-1016.

Jones, S.C., Rees, L., Hall, D., Tang, A. (2005). Using Market Segmentation Theory To Select Target Markets for Sun Protection Campaigns, Proceedings for the ANZMAC Conference, University of Western Australia, 144-149.

Kerr N.A., Fridinger F., ve Volansky M. (1999). PEP: The Personal Energy Plan: Worksite Approach to Improving Health Through Increased Phyical Activity and Healthy Eating, Social Marketing Quarterly, 5(3), 113-116.

Kirkby, R.J., Kolt, G.S., Habel K., ve Adams J. (1999). Exercise in Older Women: Motives for Participation, Australian Psychologist, 34(2), 122-127.

Kişnişçi, H., (1991). “Türkiye'de Nüfus ve Aile Planlaması Ille İlgili Faaliyetler- Aile Yazıları”, 6, Nüfus ve Aile Planlaması, AAK Yayını, Ankara, 331-336.

Kolodinsky, J. ve Reynoldsi, T. (2009). Segmentation of Overweight Americans and Opportunities for Social Marketing, International Journal of Behavioral Nutrition and Physical Activity, 6 (13), 1-11.

Kolt, G.S., Driver, R.P. ve Giles, L.C. (2004). Why Older Australians Participate in Exercise and Sport, Journal of Aging and Physical Activity, 11, 185-198.

Kotler, P. ve Armstrong, G. (2012). Principles of Marketing. 14. Ed. England: Pearson Education.

Kotler, P., Lee, N. (2008). Social Marketing: Influencing Behaviors for Good. 3. Ed. California: Sage Publication.

Kotler, P., Roberto,N. ve Lee, N. (2002). Social Marketing: Improving the Qulaity of Life, Sage Publications: California.

Maples, M.F., Abney, P.C. (2006). Baby Boomers Mature and Gerontological Counseling Comes of Age, Journal of Counseling \& Development, 84 (Winter), 3-9.

Marcus, B.H., Lewis, B.A. (2003). Physical Activity and the Stages of Motivational Readiness for Change Model, President's Council on Physical Fitness and Sporls Research Digest, 4 (1), 1 $-8$.

Mathews A.E, Laditka S.B., Laditka J.N.,Wilcox S., Corwin S.J., Liu R., Friedman D.B., Hunter R., Tseng W., and G. Logsdon R.G. (2010). Older Adults' Perceived Physical Activity Enablers and Barriers: A Multicultural Perspective, Journal of Aging and Physical Activity, 18, 119-140.

Miles, M.B. ve Huberman, A.M. (1994). Qualitative Data Analysis. 2. Ed. CA: Sage Publications. 
Milner J. (2005). The Obesity Message: Marketing Physical Activity to Large Older Adults, The Journal on Active Aging, July-August, 36-41.

Musich, S., McDonald, T., Chapman, L. (2009). Health Promotion Strategies for the Boomer Generation: Wellness for the Mature Worker, The Art of Health Promotion, January/February, 1-9.

Neiger, B.L., Thackeray, R., Barners, M., McKnezie, J.F. (2003). Postioning Social Marketing as a Planning Processfor Health Education, American Journal of Helath Studies, 18(2/3), 75-81.

Oh, E. ve Reeves, T. (2014). Generational Differences and the Integration of Technology in Learning, Instruction and Performance, Ed. J.Michael Spector vd., Handbook of Research on Educational Communications and Technology, New York: Springer.

Özcan, C. (1993). “Türkiye'de Sağlık Hizmetlerinde Organizasyon Yönetim ve Hizmet ModelleriTürkiye'de Nüfus Konuları", Ed: Aykut Toros, Hacettepe Üniversitesi Nüfus Etüdleri Enstitüsü (HÜNEE) Yayını, Ankara 1-57.

Patel, A., Schofield, G.M., Kolt, G.S. ve Keogh, J.W.L. (2013). Perceived Barriers, Benefits, and Motives for Physical Activity: Two Primary-Care Physical Activity Prescription Programs, Journal of Aging and Physical Activity, 21, 85-99.

Prochaska, J.O., DiClemente, C.C., Norcross, J.C. (1992). In Search of How of People Change; Application to $\quad$ Addictive Behavios, American Psychologist, 47 (9), 1102-1114.

Quine, S., Carter, S. (2006). Australian Baby Boomers' Expectations and Plans for Their Old Age. Australasian Journal on Ageing, 25 (1), March, 3-8.

Rayner, M. (2007). Social Marketing: How Might This Contributor to Tackling Obesity?, Obesity Reviews, 8 (1), 195-199.

Sago, B. (2000). "Uncommon Threads: Mending the Generation Gap at Work", July. Erişim tarihi: 10.02.2016.https://webcache.googleusercontent.com/search?q=cache:oppMFIDRABQJ:http s://www.asaecenter.org/Resources/articledetail.cfm\%3FltemNumber\%3D13100+\&cd=1\&hl= $\mathrm{tr} \& \mathrm{ct}=\mathrm{clnk} \& \mathrm{gl}=\mathrm{tr}$.

Sit C.H.P., Kerr, J.H., Wong, I.T.F. (2008). Motives for and Barriers to Physical Activity Participation in Middle-Aged Chinese Women, Psychology of Sport and Exercise, 9, 266-283.

Smith, B. (2009). The Power of the Product P or Why Toothpaste is so Important to Behavior Change, Social Marketing Quarterly, 15 (1), 98-106.

Stead M, Gordon R., Angus K. ve McDermott L. (2007). A Systematic Review of Social Marketing Effectiveness, Health Education, 107, 126-191.

Stein, H. P. ve Potkanowicz, E. (2003). Behavioral Determinants of Healthy Aging: Good News for the Baby Boomer Generation, Online Journal of Issues in Nursing, 8 (2), 1-27. 
Dilşad ÇOKNAZ | Meftune ÖZBAKIR UMUT | Meltem NURTANIŞ VELIOĞLU

Swan, J.H., Friis, R. ve Turner, K. (2008). Getting Tougher for the Fourth Quarter: Boomers and Physical Activity, Journal of Aging and Physical Activity, 16, 261-279.

Syme, S.L. (2002). Promoting Health and Preventing Disease: How Will We Meet the Challenge of Behavior Change?, Social Marketing Quarterly, 3 (4): 64-66.

Terzibaşığlu, H. (1964). “Türkiye'de Doğum Kontrolünün Bugünkü Türk Hukuku Yönünden Kısa Eleştirmesi”, Adalet Dergisi, 55 ( 5-6), Mayıs-Haziran, 556.

Thøgersen-Ntoumani, C. (2009). An Ecological Model of Predictors of Stages of Change for Physical Activity in Greek Older Adults, Scandinavian Journal of Medicine and Science in Sports, 19, 286- 296.

Tobin, G.A., ve Begley, C.M. (2004). Methodological Rigour Within a Qualitative Framework, Journal of Advanced Nursing, 48(4), 388-396.

Tolbize, A. (2008). Generational Differences in the Workplace, Minnesota: Research and Training Center on Community Living.

Truong, D. (2014). Social Marketing: A Systematic Review of Research 1998-2012, Social Marketing Quarterly, 20 (1), 15-34.

Truong, D., Garry, T. ve Hall, M. (2014). Social Marketing as the Subject of Doctoral Dissertations, Social Marketing Quarterly, 20 (4),199-218.

TÜik (2013). Erişim Tarihi: 26.05.2016, http://www.tuik.gov.tr/PreHaberBultenleri.do?id=16057.

тÜik (2015). “Genel Nüfus Sayımları-1927-2000” Erişim Tarihi: 26.05.2016, http://www.tuik.gov.tr/PreTablo.do?alt_id=1047.

Türkiye Fiziksel Aktivite Rehberi (2014). Ankara: Sağlık Bakanlığı Yayınları.

U.S. Department of Health and Human Services (1999). Promoting Physical Activity: A Guide for Community Action, Human Kinetics, USA.

Weinreich, N. K. (1999). Hands On Social Marketing, A Step By Syep Guide, California: Sage Publication.

WHO (2016). Erişim tarihi: 26.05.2016, http://www.who.int/dietphysicalactivity/factsheet_inactivity/en/.

ww.medic8.com/healthguide/elderly-care/healthy-lifestyle.html, Erişim tarihi: 08.06.2015.

www.des.nh.gov/organization/grant_outreach_guides.pdf, Erişim tarihi: 26.05.2016.

www.who.int/chp/about/en/, Erişim tarihi: 08.06.2015. 
Eskişehir Osmangazi Üniversitesi Sosyal Bilimler Dergisi

Yıldırım, A. ve Şimşek, H. (2013). Sosyal Bilimlerde Nitel Araştırma Yöntemleri, Ankara: Seçkin Yayınclik. 